\title{
Choosing a Republican Head of State
}

\author{
George Winterton
}

T

The most appropriate method for choosing the head of state of an Australian republic obviously depends upon the role to be performed by, and the powers conferred on, the office. Thus, a head of state with substantial executive power requires the legitimacy and popular mandate conferred by popular election as, for example, in the United States, Latin America and France. Conversely, a head of state exercising few independent powers except, perhaps, that of ultimate constitutional guardianship, requires above all political neutrality and bipartisan acceptance, and should not possess an independent popular 'mandate' for anything other than constitutional guardianship. Hence, popular election would not be ideal for such an officer, although Ireland demonstrates that it is not incompatible with a head of state with very limited powers.

Since the method of removing the head of state will affect the independence and, therefore, the effective power and influence of the office, the method of selecting the head of state cannot be divorced from the method of removal. A head of state appointed by the Prime Minister but removable only by a two-thirds majority in Parliament, for example, would enjoy greater independence than one elected by a two-thirds parliamentary majority but removable at the whim of the Prime Minister. The various grounds and methods of removal warrant an article in themselves, but it is generally assumed that a republican head of state would enjoy greater security of tenure than the Governor-General (who effectively has none) and, as a bare minimum, would be removable by Parliament (by an absolute majority of the members of each House or of both Houses jointly) only on the ground of unfitness for office. Indeed, the head of state is likely to enjoy a more secure tenure than that, being removable by Parliament only on the ground of 'proved misbehaviour or incapacity' established to the satisfaction of a Judicial Tribunal ${ }^{2}$ or, perhaps, by a two-thirds majority in Parliament on the lesser ground of unfitness for office.

The Commonwealth government will shortly announce its proposals for an Australian republic; the Terms of Reference of the Republic Advisory Committee (RAC), established in April 1993, and occasional remarks by the Prime Minister suggest that it will retain our current 'Washminster' system of government. This is

\footnotetext{
${ }^{1}$ See generally Republic Advisory Committee (RAC) (1993a:74-82); Winterton (1994a:1 15-18).

${ }^{2}$ See for example Winterton (1994b: 19-20 (s.60(3) and (4)).

3

CF. Hirst (1994:1 29-30) (s.67); Turnbull (1993:271) (specifying no ground).
}

George Winterton is Professor of Law at the University of New South Wales. 
supported by public opinion polls, which indicate a three-to-one preference for retaining our current system of government over adopting the United States system. Hence, consideration of the method of selecting an Australian republican head of state should be based upon the premise that the office will essentially replicate that of the Governor-General.

Thus, the Australian head of state will essentially act as the personification of the Australian nation. Most of the head of state's time will be spent on ceremonial functions, such as opening Parliament and swearing in Ministers, or encouraging and rewarding worthwhile national endeavours by conferring honours, recognising past achievements and sacrifices, encouraging excellence in learning, the arts and sport, and generally defining the way Australians perceive themselves. The head of state's role as constitutional guardian will be exercised day-to-day through encouraging governmental legality and regularity through the work of the Federal Executive Council (if it is retained) and suggestions to Ministers and, in exceptional and crisis situations, through exercise of the reserve powers. To fulfil these functions, the head of state must be a person of the utmost probity, who is seen as politically neutral and able to represent all Australians, regardless of ethnic origin, religion or political beliefs. The head of state must be a person of dignity and achievement, whom Australians respect and of whom they feel proud; a focus for national unity, stability and continuity. It is, therefore, apparent that the choice of a suitable head of state is critical to the success of an Australian republic, for the appointee will be national head of state, no longer a mere surrogate, embodying Australians' selfperception to a much greater degree than Governors-General were able to.

The possible methods of choosing such a head of state are virtually limitless, but those most likely to be considered seriously fall on a spectrum ranging from appointment by the government through election by Parliament to popular election, and they will be considered here in that order.

\section{Appointment by the Government}

Direct appointment by the government is a theoretical possibility, but such an appointee would appear to be a mere 'lackey' of the government, and therefore bereft of the independence and political neutrality necessary to fulfil the functions of the office.

Moreover, such a method of appointment would not replicate the method of appointing Governors-General, who are appointed by the monarch on the advice of the Prime Minister, whose advice is ultimately always followed. ${ }^{7}$ Since that method

${ }^{4}$ See Time (Australia), 3 January 1994, p.7 (72\%:21\%); Time (Australia), 26 April 1993, p.8 (73\%:22\%).

5

Analogious to the monarch's rights to be consulted, to encourage and to warn: see Bagehot (1867; 1963:111).

${ }^{6}$ For discussion of the office of head of state under a republic, see RAC (1993a:ch.4).

${ }^{7}$ See Commonwealth Constitution, s.2. Cf. the Australia Act 1986 (UK and Cth) s.7(5). 
has produced Governors-General who have generally performed well, it has occasionally been suggested as an appropriate model for appointing the republican head of state, with a Council of State or Constitutional Council replacing the monarch in the appointment process, and thus formally making the appointment on the nomination of the Prime Minister. Such a Council might include the Chief Justice of the High Court and former heads of state or State Governors or (less likely since they are politicians) the Speaker of the House of Representatives and the President of the Senate. ${ }^{8}$ Like the monarch, the Council could query the suggested appointment and perhaps endeavour to persuade the Prime Minister to withdraw the nomination, but if the Prime Minister persisted, it would ultimately be obliged to give way (as George $\mathrm{V}$ did in appointing Governor-General Sir Isaac Isaacs on the advice of Prime Minister Scullin in 1930). On the other hand, the Council could, of course, be given a real power of veto, but that would represent a departure from the current method of appointing vice-regal representatives.

Two considerations appear to underlie this proposal. One is the argument that past experience suggests that Prime Ministers would exercise this power responsibly. As the present Governor of Victoria recently argued,

[T]here is great merit in the system which has evolved here wherein the Governor is chosen by the Premier alone. The Premier is aware that he or she alone has to bear the responsibility for, and the judgment of, both the community and history upon the quality of the person selected. (McGarvie, 1994:151 and 48)

However, the more prosaic Council of State is unlikely entirely to replicate the role of the monarch, whose majesty and mystique may somewhat restrain Prime Ministers in nominating proposed appointees.

Second, it is sometimes suggested that suitable appointees might be unwilling to face (and possibly lose) an election by Parliament, let alone a popular election. As Governor McGarvie (1994:151 and 47-8) put it, a parliamentary election

would tend to identify the nominee in the public eye with the Premier's party. A person with a good career and reputation asked to agree to be nominated would not welcome running that gauntlet. If a person holding high office were refused parliamentary endorsement some would then question the person's fitness to hold the high office.

However, a former Governor-General has discounted such concerns, arguing that failure to secure parliamentary election would represent no disgrace. On the contrary, the honour of nomination to the nation's highest office would in itself be significant recognition of achievement, analogous perhaps to an unsuccessful nomination for a literary prize or an Academy Award (RAC, 1993a:68).

${ }^{8}$ See RAC (1993a:65); McGarvic (1994:151 and 48). 
Overall, appointment by the government has little support, either among commentators or the general public, of whom no more than 4 per cent support it in public opinion polls. A January 1995 opinion poll found Prime Ministerial selection of the head of state opposed by 91 per cent, with only 6 per cent approving. As Sir Zelman Cowen (1994:20) observes, it is virtually certain not to be the method finally adopted.

\section{Parliamentary Election}

Many commentators have recommended that the head of state be elected by the Commonwealth Parliament, with quite a diversity of specific proposals being advanced. Election by a simple majority of both Houses, sitting either separately or jointly, is occasionally advocated, but most proposals would require election by a super-majority, usually a two-thirds majority of the members of both Houses sitting jointly. ${ }^{12}$ Because, barring exceptional circumstances, neither major political party or coalition could achieve a two-thirds majority in a Senate elected by proportional representation (as it has been since 1949), achievement of such a majority would require bipartisan support, which would probably be accorded only to a highlyrespected, politically-neutral candidate; in other words, the type of person best suited to the office.

Apart from the appropriate majority, parliamentary election of the head of state raises several issues, including whether the two Houses should sit jointly or separately, who should nominate candidates, and whether the States should participate in the election.

Joint sitting. A joint sitting of both Houses is widely favoured because it would avoid disagreement or even deadlock between the Houses, and the extraordinary parliamentary setting would serve to emphasise the importance of the occasion (RAC, 1993a:66). It has been adopted in Trinidad and Tobago, and was also em-

${ }^{9}$ See Time (Australia), 26 April 1993, p.8 (4\%); Australian, 19 July 1993, p.2 (2\%); Time (Australia), 3 January 1994, p.7 (3\%); RAC (1993a:65 n.6). The AGB McNair poll published in the Bulletin does not even offer respondents this option.

10 Age, 26 January 1995, p.2; Sydney Morning Herald, 26 January 1995, p.2. 11

See, for example, Liberal Senator Baden Teague (S.A.) (L. Tingle, 'Senior Liberal Predicts Switch on Republic', Australian, 14 July 1994, p.1). Senator Teague now prefers election by a two-thirds majority in each House sitting separately (Teague, 1995:19).

12

For example, the Australian Democrats (L. Tingle, 'Democrats Endorse a Republic', Australian, 13 July 1994, p.1). See likewise Tumbull (1993:270-1); Hirst (1994:128) (s.57); Sir Rupert Hamer (1994); Western Australian Constitutional Committee (1995:79), 'on condition that proportional representation continue to be the method used to elect Senators'.

13

No party or coalition - not even the Fraser Government elected in 1975 - could have mustered a two-thirds majority at a joint sitting since 1949 (RAC , 1993a:67). 
ployed in the Third and Fourth French Republics. However, there are countervailing considerations.

Since the Senate theoretically represents the States or, more accurately, Australians voting as State electors, the Senate's participation in the election of the head of state would give the States a theoretical involvement therein. A joint sitting of both Houses dilutes the States' (theoretical) voice in the Commonwealth Parliament, especially since the membership of the House of Representatives is constitutionally required to be 'as nearly as practicable' double that of the Senate (s.24 of the Commonwealth Constitution). Thus the procedure specified by s. 57 of the Constitution represents the vindication and supremacy of democracy or representative government (embodied by the House of Representatives) over federalism (embodied by the Senate). So the election of a head of state by a joint sitting of both Houses might be seen as detracting from the federal principle underlying the constitution of the Commonwealth Parliament, and thus as needlessly antagonising the States and their defenders.

Second, the Commonwealth Parliament determines the method of electing Senators. ${ }^{14}$ Hence, provided the legislation could secure passage in the Senate or was enacted pursuant to $\mathrm{s.57}$, the current system of proportional representation producing an evenly balanced Senate could (in theory) be abandoned in favour of methods, such as those used before 1949, which produced grossly distorted Senate majorities, thereby facilitating the achievement of a two-thirds majority at a joint sitting (Abbott, 1994). This somewhat artificial spectre could also be raised against a requirement of majorities of 75 per cent, 90 per cent or even 100 per cent for that matter, so common sense and political reality should not be jettisoned entirely in considering possible future scenarios. (Moreover, the reality of the present system whereby the Prime Minister effectively appoints the Governor-General needs to be borne in mind.) However, the requirement of a two-thirds majority of the members of each House voting separately ${ }^{5}$ would reduce the risk of manipulation of the election of the head of state through changes in the method of electing Representatives and Senators.

Moreover, if the possibility of such abuse were considered a serious risk, constitutional safeguards could be introduced to counteract it. The Constitution could, for example, provide for a two-thirds majority if the Senate is elected by proportional representation but specify a greater majority if it is not. Alternatively, proportional representation of Senators could be constitutionally entrenched.

Nomination. Some commentators (for example, Turnbull, 1993:270) suggest that the proposed appointee be nominated by the government. If approval by a supermajority is required, that candidate is likely to have been agreed upon by both gov-

\footnotetext{
${ }^{14}$ Commonwealth Constitution s.9. Likewise regarding the House of Representatives: ss.31 and $51(x \times x v i)$.

${ }^{15}$ See, for example, Winterton (1994b:18) (s.59(2)).
} 
ernment and opposition prior to nomination (RAC, 1993a:68-9). This would tend to make the parliamentary election itself rather a formality. So, to offer Parliament a real choice and also ensure that a wide field of potential candidates is considered, some commentators argue that the nomination process should be taken out of the hands of parliamentarians who, it is feared, would be likely to nominate a politician or ex-politician. The requirement of bipartisan approval would not prevent this, it is said, since the politicians may enter into political 'deals' regarding occupancy of the office, or may agree to alternate the headship of state between the principal political parties (see Hirst, 1994:52).

Various forms of Nominating Commission have been proposed. John Hirst (1994:127), for example, has suggested that three persons be nominated by a Commission chaired by the Chief Justice of the High Court and also comprising the Speakers of all Australian Parliaments and 15 Companions of the Order of Australia chosen by lot, while Sir Rupert Hamer (1994) has proposed that one person be nominated by an 'Electoral College' of 20 Companions of the Order of Australia chosen by lot. In both cases, the final choice would be made by a two-thirds majority of a joint sitting of both Houses of the Commonwealth Parliament.

If such a body be considered unduly elitist, the power to nominate candidates could be given (perhaps additionally) to a prescribed number of electors, as in Portugal (whose president is popularly elected), or to a specified number of Commonwealth and/or State and Territory parliamentarians, as in Israel, Trinidad and Tobago, and Ireland (whose president is popularly elected) (RAC, 1993a:69). If the States do not participate directly in the election of the head of state, it may be appropriate to authorise State Parliaments to nominate candidates, perhaps in conjunction with other sources of nomination. (An analogy may be drawn with the requirement that State Attorneys-General be consulted on High Court appointments, which has led some States to suggest suitable candidates.) ${ }^{16}$

State participation. If, like the Queen, the national head of state exercises powers and functions in respect of the States, the latter clearly ought to participate in his or her election (see Carney, 1994:193). (If State autonomy is not to be impaired, any powers and functions in respect of the States should be exercisable only on the advice of State Ministers.) ${ }^{17}$ The case for State participation in the selection of a head of state who exercises no powers or functions in respect of them is weaker, but a case for State participation could nevertheless be made on the ground that the head of state should represent all sections of the nation and enjoy the widest possible support. John Hyde (1994) has even suggested that the head of state be chosen simply by a unanimous resolution of the Prime Minister and the State Premiers.

India and Germany provide for State (or Land) participation in presidential elections on an equal basis with the national parliament, although the upper house

\footnotetext{
${ }^{16}$ See the High Court of Australia Act 1979 (Cth) s.6.

17

C. the Australia Act 1986 (UK and Cth) s.7(5).
} 
of the German national parliament (the Bundesrat) does not participate. Regional governments similarly participate in presidential elections in (non-federal) Italy, as they also did in the Fifth French Republic before 1962, when popular election of the president was introduced. However, the Indian and German States (Länder) do not each have the same vote; rather, the vote of each representative depends upon the population of the relevant State or Land, which could prove politically controversial in Australia. Moreover, neither country really provides a precedent for State parliamentary participation in the election of an Australian head of state together with both Houses of the Commonwealth Parliament: not Germany, because the upper house of its national parliament does not participate in presidential elections; nor India, because its national head of state appoints and removes State governors and exercises powers and functions in respect of the States. It is also relevant that the German Länder do not have their own heads of state, whereas the Australian States are likely to retain separate Governors.

State participation in the electoral college which elects the national head of state would also render the process unwieldy, so that the electoral college may meet only on paper, and would certainly complicate the negotiation and compromise necessary for bipartisan agreement. Consequently, Senate participation in the election of the head of state may be considered an adequate representation of State interests, with any direct State involvement being confined to nomination of candidates.

Public support for parliamentary election of the head of state rarely exceeds 20 per cent, and a January 1995 poll evinced opposition to it in the ratio of 69 per cent to 25 per cent. ${ }^{20}$ But there is much to be said for it, for it would invest the head of state with the legitimacy derived from election by (most likely a supermajority of) the people's representatives without conferring the direct mandate of the people derived from popular election. A popularly elected head of state would be the only nationally elected public office-holder, with a popular legitimacy more direct than the Prime Minister's and more general than that of any member of Parliament. Parliamentary election, on the other hand, would effectively place the head of state on the same level of popular legitimacy as the government, both ultimately deriving their authority from Parliament (the government, strictly speaking, from the House of Representatives). While it is true that it would be a rare government which could claim the support of two-thirds of the members of the House of Representatives (let alone of both Houses), the head of state's authority would be limited to the exercise of the specific powers vested in the office, while the government

\footnotetext{
${ }^{18}$ See the Indian Constitution arts. 155, 156(1) and 356.

19

See Time (Australia), 26 April 1993, p.8 (21\%); Bulletin, 11 May 1993, p.14 (8\%); Australian, 19 July 1993, p.2 (10\%); Bulletin, 19 October 1993, p.13 (169); Time (Australia), 3 January 1994, p.7 (18\%); Bullecin, 15 February 1994, p.18 (5\%); Bulletin, 30 August 1994, p.10 (9\%); Bulletin, 8 November 1994, p.32 (8\%).

20

Age, 26 January 1995, p.2; Sydney Moming Herald, 26 January 1995, p.2. There was slightly less opposition to election by a 'representative group of State and federal parliamentarians': 65\% to $27 \%$.
} 
would enjoy the mandate to govern derived from the continuing confidence of the House of Representatives.

The nomination of candidates and the procedure for voting thereon (no debate?, secret ballot?) are obviously important, but it would be dangerous to specify them in a constitution as difficult to amend as Australia's, since it may prove impossible to alter aspects which prove unsatisfactory. Hence, it would seem preferable to authorise Parliament to regulate these matters either by ordinary legislation (see, for example, Winterton, 1994b:18 (s.59(4))) or, if considered appropriate, by legislation enacted by the same super-majority as elects the head of state. It would also be wise to introduce a constitutional provision to encourage successful completion of elections of the head of state by prohibiting the prorogation or adjournment of Parliament until a candidate had been elected (Winterton, 1994b:18 (s.59(3))).

\section{Popular Election}

Public opinion polls reveal very strong support (around 80 per cent) for popular election of the head of state of an Australian republic. In a February 1994 poll offering a choice between parliamentary and popular election, the latter achieved a remarkable 91 per cent, ${ }^{21}$ and a January 1995 poll indicated support for popular election in the order of 88 per cent to 9 per cent. ${ }^{22}$ The public understandably wishes to have a say in the selection of the head of state, but ironically a frequent motivation seems to be to avoid the selection of a politician or ex-politician (RAC, 1993a:70; Mackay Research, 1994:15-18). Yet, unless careful measures were introduced to prevent it, popular election would be likely to produce a politician, or at least the nominee of a major political party, for only the political parties or the extremely wealthy could afford a national election campaign. As Gough Whitlam (1994) recently remarked, 'there is no surer way of absolutely guaranteeing that the President of Australia will always be a party politician than by making the presidency directly elective'.

A popularly elected head of state would symbolise the popular sovereignty underlying the notion of a republic, and so may appear philosophically most compatible with republicanism. But practical considerations counsel against it. First, a national election campaign (which the Irish experience suggests may effectively become a vote on the popularity of the government - see Duffy, 1993:paras 3.21, $3.29,3.35,3.42,3.45$ and p.179) may appear incompatible with the political neutrality necessary for a head of state in the 'Westminster' system. A candidate winning 51 per cent of the vote may find it difficult to be perceived as a unifying symbol of the entire nation. Sir Robert Menzies (1967:236) once remarked that 'the notion of

${ }^{21}$ See Time (Australia), 26 April 1993, p.8 (71\%); Bulletiu, 11 May 1993, p.14 (83\%); Australian, 19 July 1993, p.2 (79\%); Bulletin, 19 October 1993, p. 13 (80\%); Time (Australia), 3 January 1994, p. 7 (76\%); Bulletin, 15 February 1994, p.18 (91\%); Bulletin, 30 August 1994, p.10 (86\%); Bulletin, 8 November 1994, p.32 (90\%).

22

Age, 26 January 1995, p.2; Sydney Morning Herald, 26 January 1995, p.2. 
a non-political President periodically elected by popular vote, after an election campaign, is a contradiction in terms'. Yet Ireland and Austria, both republics with a parliamentary executive, have demonstrated that popular election is not incompatible with a politically neutral head of state. ${ }^{23}$ However, worthy candidates from outside politics may well prove reluctant to subject themselves to popular election (RAC, 1993a:71). The experience of Austria and Ireland ${ }^{24}$ suggests that, although popular election generally produces heads of state with a political background, that is not inevitably the case.

The involvement of political parties in elections for the head of state could be reduced by specifying qualifications for candidacy designed to open the process to non-politicians, combined perhaps with public funding of election campaigns. Thus, the Nominating Commissions noted above (p.140) could be employed for popular elections, or parliamentary and popular election could effectively be combined, as Hugh Mackay (1994) has suggested, by limiting the popular election to a choice between three candidates (including at least one man and one woman) selected by a two-thirds majority of a joint sitting of both Houses of the Commonwealth Parliament.

Second, a popularly elected head of state may be tempted to interfere improperly in governmental affairs through belief that popular election had conferred a 'mandate' equal, if not superior, to that of the government, whose Prime Minister was never personally elected in a national ballot. As Sir Zelman Cowen (1994:20) recently remarked, a popularly elected head of state 'would have a strong constitutional base to confront effectively a prime minister with high and threatening personal aspirations'. He rightly considered this 'appalling' if we intend to retain our present system of government, for competition and division at the highest levels of the executive could prove very destabilising. ${ }^{25}$ The Leader of the Opposition has similarly warned that popular election of the head of state

would alter for all time the nature of our system of government. It would entrench rival centres of political power. . . [A]n Australian president, having a popular mandate, would feel infinitely more powerful in dealing with an incumbent Prime Minister than would any Governor-General, irrespective of the formal powers which might be given to that president. (Howard, 1994:130-1)

\footnotetext{
${ }^{23}$ For Austria, see Raschauer (1993:31, 40). The Irish President's powers are so limited that little opportunity for political partiality has arisen.

${ }^{24}$ For the presidents of Austria and Ireland, see RAC (1993b:47-50, 162-76. (The non-politician Presidents of Austria were Kirchschläger (1974-86), Waldheim (1986-92) and Klestil (1992- ) and, of Ireland, Hyde (1937-45) and arguably $O$ Dálaigh (1974-76), who had been a judge (including Chief Justice) for 21 years before becoming President.)

25

Malcolm Fraser (1994) has expressed a similar view. For a different perspective, see Evans (1993).
} 
France's change to popular presidential election in 1962 demonstrated that alteration of the method of election alone, without the conferral of any additional constitutional power, could substantially enhance the political power of the head of state relative to that of the government (Wright, 1983:25). As two leading American commentators noted in 1954,

Direct election gives the Head of State political authority even without express constitutional provision. It also tends to make him a partisan and though the purpose of direct election is to provide an embodiment of the federation, it destroys that air of neutrality that both the ceremonial functions in any federation and the specific powers under a Parliamentary system demand. (Friedrich \& Guttman, 1954:74).

Forty years later former Australian Prime Minister Malcolm Fraser (1994) similarly remarked that a directly-elected head of state would '[from] that process alone, have authority and a capacity to compete in some things with the prime minister. That could usher in a period of instability'.

Consequently, popular election of an Australian head of state would raise the prospect of a substantial change in the balance of power between the head of state and the executive government, and thus in the system of government, leading to calls for close definition of the head of state's powers (RAC, 1993a:72-3; Turnbull, 1994:xii). This in turn would rekindle the old controversy regarding the wisdom of codifying the reserve powers and thereby diminishing the flexibility of the head of state's possible response to a governmental crisis. The wording of specific provisions would also prove controversial, and any attempt to resolve the contentious issue of how the head of state should respond to a denial of Supply by the Senate could completely derail the advent of a republic. Moreover, as Ireland realised, a head of state's possible intervention in governmental affairs need not be confined to the exercise of constitutional power, but extends to public commentary.

These considerations suggest that popular election is not the ideal method for producing a politically neutral head of state enjoying broad community support, and exercising only sufficient independent power to enable him or her to act as the ultimate guardian of the Constitution by refusing to dissolve Parliament or dismissing a government which flagrantly contravenes the Constitution. However, if public support for popular election persists, the government may feel obliged to concede it notwithstanding its reservations, ${ }^{27}$ especially since recent public opinion polls sug-

\footnotetext{
${ }^{26}$ See the Irish Constitution art. 13.7, discussed in Duffy (1993:132-3). 27

See, for example, Commonwealth Attorney-General Michael Lavarch, opposing popular election of the head of state and favouring election by Parliament by a special majority (M. Millett, 'No People's Vote for Republic Head: Lavarch', Sydney Moming Herald, 5 October 1994, p.14; R. Eccleston, 'Lavarch Against Presidential Poll', Australian, 5 October 1994, p.1).
} 
gest that it may affect the outcome of the referendum to establish a republic. ${ }^{28}$ In that event, care should obviously be taken to address the two major concerns noted here: the electoral process should be opened to ensure participation beyond the political parties, and checks and balances should be introduced into the Constitution to preserve the present balance of authority between the Governor-General and the elected government. (For a suggested check, see Winterton, 1994c:53.)

\section{Conclusion}

The constitutional amendments to achieve a republic must be passed by the Commonwealth Parliament (or passed twice by one House) and approved by the electors (a national majority and a majority in four States) in a referendum pursuant to s.128 of the Commonwealth Constitution. Hence, wide public consultation and discussion are appropriate before the proposals are even framed.

Some commentators have advocated a popularly elected Convention modelled on that which drafted the existing Constitution in 1897-98. ${ }^{29}$ But present circumstances are not parallel with those of a century ago, when there was no constitutionally ordained process for approving the proposed Constitution before its ultimate enactment at Westminster. Moreover, it needs to be remembered that the delegates elected in 1897 were virtually all current or former politicians, as one would expect, and as would be the case today. So, ironically, a wider cross-section of the public might be drawn into the process of constitutional change if the Convention were not popularly elected.

While a Convention empowered by popular mandate may be appropriate if a thorough-going constitutional revision were contemplated (in which case the government should undertake to put the Convention's proposals to the electors, albeit not necessarily with its endorsement), such a grand and costly venture would seem inappropriate for the more modest task of framing republican proposals and possibly considering one or two other issues, such as aboriginal reconciliation and reform of federal financial relations.

Hence, as the present writer has argued elsewhere, the proposals for an Australian republic should be settled at a Convention composed equally of parliamentari-

\footnotetext{
An AGB McNair poll in August 1994 asked: 'Would you support a move toward a republic if the head of state was elected by Parliament?' 32\% answered 'yes'; 51\% 'no'; and 17\% were undecided: Bulletin, 30 August 1994, p.10. In the same poll, $45 \%$ favoured a republic, $42 \%$ were opposed, and $13 \%$ were uncommitted. Similarly, another AGB McNair poll in January 1995 found that if popular election of the head of state was excluded, support for a republic fell by 12 percentage points (from $52 \%$ to $40 \%$ ), while opposition rose 10 percentage points (from $38 \%$ to $48 \%$ ) (Age, 26 January 1995, p.2; Sydney Monning Herald, 26 January 1995, p.2).

29

See Lumb (1992; 1993/94); Constitutional Centenary Foundation (1993); Fraser (1994). But $c f$. Centenary of Federation Advisory Committee (1994:40).

30

See La Nauze (1972:100-04); Quick \& Garran (1901:164-5); de Garis (1993:101); Twomey (1994:17). (Only one delegate elected in 1897 had never been a Member of Parliament.)
} 
ans and non-parliamentarians, the latter selected by all Australian legislatures on a bipartisan basis from a wide cross-section of the community. Ideally, it should be convened in Perth or Hobart in March 1997, the centenary of the earlier Convention (Winterton, 1993).

\section{References}

Abbott, T. (1994), 'Fail-Safe Republic Can't Keep Keating Off the Controls', Australian, 19 May: 11.

Bagehot, W. (1867;1963), The English Constitution, Fontana, London.

Carney, G. (1994), 'Republicanism and State Constitutions', pp.183-210 in M. Stephenson \& C. Turner (eds), Australia: Republic or Monarchy?, University of Queensland Press, Brisbane.

Centenary of Federation Advisory Committee (1994), 2001: A Report from Australia, AGPS, Canberra.

Constitutional Centenary Foundation (1993), 'If We Wanted to Review the Constitution, How Would We Do It?', Constitutional Centenary, Supplement to vol. 2, no. 4, Constitutional Centenary Foundation, Melbourne.

Cowen, Sir Z. (1994), 'Reflections on an Australian Republic', Quadrant 38(12): 14-21.

de Garis, B. (1993), 'How Popular was the Popular Federation Movement?', pp.101-12 in Parliament and the Constitution: Some Issues of Interest, Department of the Senate, Canberra (Papers on Parliament No. 21, December)

Duffy, J. (1993), 'Ireland', in RAC (1993b:109-85).

Evans, H. (1993), 'The Agenda of the True Republicans', pp.3-7 in G. de Q. Walker et al., Restoring the True Republic, Centre for Independent Studies, Sydney. Reprinted in H. Evans, Essays on Republicanism: small $r$ republicanism, Department of the Senate, Canberra (Papers on Parliament, No. 24, September 1994).

Fraser. M. (1994), 'We Must Bounce Keating's Republic Blank Cheque', Australian, 20 July: 11.

Friedrich, C. \& R. Guttman (1954), 'The Federal Executive', pp.63-105 in R. Bowie \& C. Friedrich (eds), Studies in Federalism, Little, Brown, Boston.

Hamer, Sir R. (1994), 'Change Inevitable, But Langely Symbolic', Canberra Times, 9 July: 12.

Hirst, J. (1994), A Republican Manifesto, Oxford University Press, Melbourne.

${ }^{31}$ Former federal Opposition Leader Alexander Downer proposed a somewhat similar Convention for 1997, with half its members appointed by Commonwealth, State and Territory governments, and half popularly elected (R. Peake, 'Downer Signals Future Direction', Canberra Times, 18 November 1994, p.2). The present Leader of the Opposition, John Howard, has stated that he will honour that commitment (D. Humphries, 'Avowed Non-Republican Keeps Mum on Monarchy', Australian, 31 January 1995, p.7.) Such a Convention may excite greater interest and enthusiasm than the model proposed here, but it would probably be more politically partisan (even if politicians and party endorsement were excluded from the popular election), and certainly far more costly. 
Howard, J. (1994), 'Mr Keating's Mirage on the Hill: How the Republic, Like the Cheshire Cat, Came and Went', pp.115-33 in Upholding the Australian Constitution, Volume 3: Proceedings of the Third Conference of The Samuel Griffith Society, Melbourne.

Hyde, J. (1994), 'Beware the Ides of March', Australian, 15 July: 7.

La Nauze, J. (1972), The Making of the Australian Constitution, Melbourne University Press, Melbourne.

Lumb, R. (1992), 'Methods of Constitutional Revision in the Federal Sphere: An Elected Constitutional Convention?', University of Westem Australia Law Review 22: 52-71.

(1993/94), 'Elected Conventions \& Constitutional Change', Policy 9(4): 43-4.

Mackay, H. (1994), 'Stability for the Commonweal', Weekend Australian, 30-31 July : 16.

Mackay Research (1994), The Republic, Sydney (The Mackay Report: Keynote, May).

McGarvie, R. (1994), 'Governorship in Australia Today', Parliamentarian 75: 149-54. Also published in Victorian Bar News 90: 45-52.

Menzies, Sir R. (1967), Aftemoon Light, Cassell, Melbourne.

Quick, J. \& R. Garran (1901), The Annotated Constitution of the Australian Commonwealth, Angus \& Robertson, Sydney.

Raschauer, B. (1993), in RAC (1993b:20-51).

Republic Advisory Committee (RAC) (1993a), An Australian Republic: The Options - The Report, AGPS, Canberra.

- (1993b), An Australian Republic: The Options - The Appendices, AGPS, Canberra.

Teague, B. (1995), An Australian Head of State: The Contemporary Debate, Occasional Lecture, Parliament House, Canberra, 31 March.

Turnbull, M. (1993), The Reluctant Republic, Heinemann, Melbourne.

- (1994), The Reluctant Republic (reprint), Mandarin, Melbourne.

Twomey, A. (1994), The Constitution-19th Century Colonial Office Document or a People's Constitution?, Parliamentary Research Service, Canberra (Background Paper No. 15).

Western Australian Constitutional Committee (1995), Report, Perth, January.

Whitlam, G. (1994), 'The Seed From Which a Republic Sprang', Canberra Times, 12 November: 12.

Winterton, G. (1993), 'Change Must be Slow, Gradual', Weekend Australian, 9-10 October: 32.

— (1994a), Monarchy to Republic: Australian Republican Government (revised ed.), Oxford University Press, Melbourne.

- (1994b), 'A Constitution For an Australian Republic', pp.1-37 in G. Winterton (ed.), We, the People: Australian Republican Government, Allen \& Unwin, Sydney.

- (1994c), 'Presidential Reserve Powers in an Australian Republic', Legislative Studies 8(2): 47-55.

Wright, V. (1983), The Govemment and Politics of France (2e), Hutchinson, London. 